\title{
Effect of the Socioeconomic Characteristics of Borrowers on Microcredit Repayment Behaviour: An Application to a Category II Microfinance Institution in Cameroon
}

\author{
Ntieche Adamou ${ }^{1,2}$, Forbeneh Agha Jude ${ }^{1}$, Mbondo Georges Dieudonné $^{1,2} \&$ Bilguissou Abba $^{3}$ \\ ${ }^{1}$ University of Douala, Faculty of Economics Sciences and Applied Management, Cameroon \\ ${ }^{2}$ University of Douala, Laboratory of Applied and Theoretical Economics, Cameroon \\ ${ }^{3}$ University of Yaoundé II Soa, Faculty of Economics Sciences and Management, Cameroon \\ Correspondence: Ntieche Adamou, University of Douala, Faculty of Economics Sciences and Applied \\ Management, Cameroon. Tel: 237-668-425-612/ 696-530-590. E-mail: ntadams2003@gmail.com
}

Received: May 21, 2020; Accepted: June 4, 2020; Published: June 15, 2020

\begin{abstract}
The purpose of this study is to determine the influence of socioeconomic characteristics of borrowers on microcredit repayment behaviour. The results of Probit regression statistical analysis using a database of 1805 individual loan contracts, credit records and follow-up files from 2007 to 2014 period by Community Credit of Africa (CCA) in Cameroon, reveal that educational level, awareness about the location of business and/or home of borrowers by the lender, sector of activities, availability of collateral, income stability, and personal wealth of borrowers have a statistically significant influence on microcredit repayment behaviour of borrowers. The outcome of the results shows that microfinance institutions should not only rely on financial indicators to assess the creditworthiness of borrowers. Other factors belonging to the social and economic characteristics of the borrowers are supposed to be integrated in credit risk models. These factors are sought to influence significantly microcredit repayment behaviour of borrowers.
\end{abstract}

Keywords: borrowers' behaviour, microcredit, MFIs, socioeconomic characteristics

\section{Introduction}

The multiplicity of bankruptcies related to microfinance institutions; especially, category II microfinance institutions in Cameroon, with an estimated saving of 45.5 billion FCFA (Note 1) for the period from 2002 to 2014 , urged the questioning of the link between the socioeconomic characteristics of borrowers and microcredit repayment behaviour. In Africa, the era of microfinance commenced with the banking crisis of the late 1980s; underpinned by a tradition of informal finance. Major indicators sourced from the survey carried out by the Cameroon Ministry of Finance in 2013, and statistics from COBAC (Note 2) ((2015) advocated that the microfinance activity in Cameroon is growing rapidly, and experiencing a series of restructuring and consolidation. Meanwhile, according to the report of COBAC (2014), from a total of about 600 MFIs in 2002, more than 198 MFIs became bankrupt between 2002 and 2012, representing a dissolution rate of 33 per cent. In the same vein, the statistical survey conducted in 2013 by the DGTCFM (Note 3) of the Ministry of Finance of Cameroon indicated that this sector consisted of only 399 MFIs (Note 4) at the end of 2012.

Indeed the real rate of bankruptcy culminated to 39 per cent, representing an annual rate of 3.9 per cent. Also, we observed that 46.7 per cent of the MFIs that were bankrupt are of the second category with an estimated savings of above 45.57 billion FCFA. The predominant cause of bankruptcy within microfinance institutions is the default on microcredit repayment. From this report, Community Credit of Africa (CCA) for the period 2007 to 2014 is one of the category II MFIs that scored a high credit performance in terms of lending and loan recovery. These figures justify both the significance and the interest to focus our study on this category of MFIs. Basically, enormous bankruptcy experienced by MFIs, with its major financial and social consequences, it is necessary to question the link between socioeconomic characteristics of borrowers and their microcredit repayment behaviour.

Indeed, the premature demise of multitude microfinance institutions in Cameroon might be caused by default payment on loans. For many decades, the financial sector of Cameroon has unprecedentedly encountered dissolution of MFIs. Obviously, MFIs may discontinue operations; whenever, huge amount of microcredit is unrecovered because borrowers default on payment. Naturally, enormous amount of loan delinquency is likely to 
cause the failure of MFIs. Therefore, it is imperative to provide particular interest on the microcredit repayment behaviours of borrowers in order to avoid a downturn on the activities of MFIs. Lending is indispensable within the sector of MFIs, and may orchestrate high credit risk leading to devastating effects on the activities of MFIs. As a result, it is essential to study the influence of socioeconomic characteristics of borrowers on microcredit repayment behaviour. Thus, the main question of this study is: "What is the influence of the socioeconomic characteristics of borrowers on microcredit repayment behaviour?

The main objective of this study is to determine the influence of socio-economic characteristics of borrowers on microcredit repayment behaviour. In fact, achieving this objective has several interests, amongst which is the necessity to resolve informational problems faced by second category MFIs. Indeed, the empirical dimension of the findings provides practical solution to the persistent problem face by MFIs in Cameroon for many decades. Meanwhile, resolving this problem requires a thorough analysis of the complex phenomenon of bankruptcies face by microfinance. Sincerely, understanding borrowers' behaviours related to the repayment of loans will enable loan committee of MFIs to anticipate and reduce default risks; and hence, to mitigate both adverse selection and moral hazard problems resulting from information asymmetry (Ntieche, 2018). Henceforth, the lending committee of MFIs might include in their lending decisions both social and economic characteristics as potential indicators predicting either default or not on loans. Basically, it is necessary to predict microcredit repayment behaviour of borrowers from their socioeconomic characteristics.

\section{Theoretical Foundations and Hypotheses}

In accordance to the neoclassical view relative to the neutrality of financial intermediaries (Theorem of Modigliani and Miller in 1959), it is irrelevant to emphasise on information because of the neutrality of financial intermediaries. Such a reasoning urged researchers to demonstrate that the "raison d'être" of banks is characterised by their potential to disclose valuable information concerning the quality of a project or borrower. However, opportunistic behaviour resulting from the exploitation of hidden actions prior to the implementation of the contract is not observable by one of the parties. This led to the analysis of informational issues in MFIs.

\subsection{Overview of Socioeconomic Characteristics of Borrowers}

It is always difficult to enumerate exclusively the factors causing default borrowing. The causes are very numerous, and their combination compromises the survival of microfinance institutions. The importance of this phenomenon and its impact on the economy as a whole, leads to determining its causes and origins in order to explain it and to be able to take preventive measures accordingly. A wide variety of causes have been presented in different works. However, the majority of studies contended that two broad categories of factors can be identified: firstly, the microeconomic causes are endogenous causes. They represent the specific risk of internal origin, and find their source in the fundamental functions of the bank, mainly production, marketing or organization. Secondly, the macroeconomic causes are exogenous elements which constitute in some cases, the main causes of the failure of borrowers. In fact, since the 1980 s, it has been observed that, apart from financial ratios, there are other cyclical type variables linked to the economic environment, the relevance of which is indisputable in explaining the phenomenon of failure and determining its causes. Investigation into the causes of the failure of borrowers allows us to highlight indicators of distress and performance that can help explain certain banking practices in terms of investment and financing. On the other hand, apart from economic indicators, there exist other social factors from the borrowers that could as well predict their potential to default on loan repayment. As a result, it is essential for microfinance institutions to readily integrate both social and economic variables in lending assessment model.

\subsection{Microcredit Loan Payment Behaviour of Borrowers}

As with all crises, borrower default is seen as a problem only by those who are directly or indirectly being victimised, and must bear the consequences. The default is not the exclusive domain of the borrowers. The assessment of the risk of default of a borrower has long been at the centre of the concerns of researchers and professionals in the field of finance. Default situations affect the life of a borrower and represent a very high cost for banking institutions in the event of partial or total loss of the loaned funds, but also a major risk for other creditors; who, as a result, can in turn become defaulting. In its common and legal sense, the default covers a whole series of situations which contribute to the disappearance of the bank due in particular to serious financial problems which lead to the cessation of payment. Blazy et al (1993) define default as "the situation from which a recovery procedure is opened against a company (lender / borrower)". Liang et al. (2003), Hol et al. (2002) believe that default is a situation where the cash flows generated by companies do not allow them to honour their commitments with financial and non-financial partners. Sharabany (2004) considers that there is a failure in each of these three cases: the activity of the company is discontinuous:- either this activity does not generate adequate profitability, or it is the subject of " a judicial declaration of insolvency. Pompe and Bilderbeek (2004), Pindado and Rodrigues 
(2001), Atiya (2001) and Varetto (1998) consider that the concept of default is in principle linked to credit risk, since it is the banks that declare that a business is insolvent when they are unable to honour their financial obligations. Thus, borrowers may adopt specific behaviour related to their loan repayment. These behaviours may concern the desire to either default on loan or to honour financial obligations.

\subsection{Microfinance Institutions in Cameroon}

As of December 31, 2008, the microfinance sector had 460 EMFs (Note 5) divided into 206 independent EMFs and 254 EMFs affiliated to a network. The sector has six (6) networks: CAMCCUL (Note 6) (177 EMF), CVECA (Note 7) Centre region (33 EMF) and CVECA Grand Nord (8 EMF), CMEC (Note 8) Western region (19 EMF), CMEC Nord-west region (8 EMF) and CMEC 'Grand-Nord' (9 EMF). The sector is dominated by first category EMF which represents 94 per cent of approved establishments Cameroon. About 82 per cent of approved EMFs that participated in the survey, i.e., 376 establishments including 352 first category EMFs and 24 second category establishments. EMFs operate through 998 branches, 525 of which are located in urban areas and 473 in rural areas. Urban settlements are mainly found in Douala (169) and in Yaoundé (155 agencies).

These points of sales are generally opened by 1st category EMFs (718 agencies), in particular by those operating in a network which identify 389 agencies including 230 for the CAMCCUL network. The expansion of activities was partly hampered by the drop in the number of ATMs (Note 9). This went from 1,111 at the end of September 2007 to 983 at the end of 2008. Despite a temporary decline observed between the last survey and December 31, 2007 (- 54,828 customers), the sector's customers recorded a growth of 18 per cent in annual variation as of December 31, 2008, to stabilise at 1,073,621 clients. 57 per cent of these customers come from 1st category EMFs. With 252,629 members, CAMCCUL is the largest in terms of membership, followed by Community Credit of Africa (CCA), which has 116,658 members. The microfinance sector employs 6,000 employees for the operation of its activities, including 732 managers. The equity of Cameroon's MFIs has dropped. It stood at 14,021 M as of December 31, 2008 against 20,136 M a year earlier. This 30 per cent drop is explained by the deterioration in the financial situation of certain MFIs. For example, four MFIs facing difficult situations had a negative equity capital of 13,382 M at the end of 2008. In particular, the situation of category II EMFs requires increased surveillance because of the risk they induce to the financial system. Their aggregated equity stood at - $63 \mathrm{M}$. In addition, the deficits generated by the sector in $2007(7,963 \mathrm{M})$ and 2008 (5,567 M), which affected equity, the shares within the market for capital in equity decreased. Aggregate share capital stood at 22,232 million at December 31, 2008, compared to 25,000 million at September 30,2007. The CAMCCUL network, with 4,779 million at the end of 2008, was the best performing in this area, followed by COFINEST (Note 10) $(1,109 \mathrm{M})$ and CCA (1072M). Financial intermediation activities show a contrasting development. Resources stand at 258,220 M, an increase of 35 per cent compared to December 2007. More than 20 EMFs have deposits of more than one billion. Meanwhile, half of these establishments operate in the second category. With 74,890 M, CAMCCUL network collecting most of the deposits; followed by CCA $(33,176 \mathrm{M})$, then COFINEST $(17,967 \mathrm{M})$ and First Trust $(14,481 \mathrm{M})$. The resources collected represent around 80 per cent of the total outstanding deposits at December 31, 2008. As at December 31, 2008, customer loans amounted to $138,523 \mathrm{M}$, that is, beyond 22 per cent compared to the end of December 2007. This mainly concerns granting short-term cash assistance (almost 63 per cent) to finance working capital needs of traders (39 per cent), consumption (27 per cent) and the provision of funds to SMEs (Note 11) and SMIs (Note 12) (21 per cent). CAMCCUL manages 32 per cent of the market share, with 44,892 M in loans distributed. Credit coverage by deposits remains comfortable. It stood at 186 per cent at the end of December 2008 marking a good liquidity situation, which gives preference, to the detriment of financial intermediation, to the provision of services and explains the need to have an adequate situation of cash. However, the quality of the MFI portfolio has deteriorated. Bad debts increased from $23114 \mathrm{M}$ to $35553 \mathrm{M}$ over the period of investigation. They represent more than a quarter (1/4) of microcredit granted to customers in December 2008 and were only provisioned at 34 per cent. This under-provisioning dissimulated the reality of the sector's profitability. Nonetheless, category II EMFs present a less favourable situation, and a third of the loans granted were compromised at December 31, 2008.

\subsection{Overview of Informational Issues in Microfinance Loans}

The agency theory postulated by Jensen and Meckling (1976) inspired many of the models of optimal credit agreements. For instance, shareholders of a firm do not have the same interests as creditors and have more specific information about the quality of their project. The agency theory examines how informational asymmetries and the difficulty of observing agents by the principals can be overcome by setting contractual terms that either provide incentive or coerce measures for the agents to act according to the interest of the principal. For example, Diamond (1984) proposed a non-contingent contract where repayments are made on a flat-rate basis and coordination principles are reduced to the extreme in order to minimize the cost of control. It is important to know that in 
individual or group borrowing schemes, if the quality of the borrowers may have a positive or somewhat negative impact with a few exceptions.

\subsubsection{The Specificity of Individual Loans in Microfinance}

Various strategies implemented by MFIs may urge bad clients to disclose their qualities; and thus in turn will decrease the default risk, helping the MFIs to tailor their contractual terms to suit types of clients. As a result, it is necessary to reject unperformed credit managers among the members of a group. Consequently, borrowers providing little effort will be excluded from subsequent credits schemes. In accordance, pressure will increase in the group, causing the exclusion of borrowers with unperformed loans from future lending programmes. Meanwhile, granting premium (or bonus) to encourage relevant effort is intended to create an incentive within the group and to mitigate the risk of credit default. Apparently, the introduction of bonus to compensate effort, MFIs create an incentive, and hence, remain indifferently to the type of credit contract. Therefore, the search of information is determined by the degree of effort and the characteristics of customers. For instance, Holmstrom and Tirole (2000) show that risk coverage is a means to improve the accuracy of information. These authors advocated the regulation of the banking system as well. On the other hand, Holmstrom (1982) and Mookherjee (1984) argued that projects carried out by different agents disclose valuable information on them. According to Julien and Salanié (2001), adverse selection concerns the risk aversion of agents. In the same trend, Stewart (1994) argues that adverse selection is about the costs of individual protection. Stewart (1994) considers that the level of protectionism and the associated cost are known only to the agent. Thus, bad borrowers will improve their efforts to obtain a high premium and benefit from a renewal form of contract.

\subsection{The Microfinance Revolution through Microcredit}

Most microfinance institutions revamp their financial activities practices by including new services into the sector. However, despite the high pace development of this sector and the spurring innovation, one of a major difficulties that microfinance institutions face today is the implementation of attractive mechanisms to counteract 'bad' loans and the problems related to the repayment of microcredit due to asymmetric information that boils down to moral hazard, adverse selection and other risks.

\subsubsection{The Effectiveness of Microcredit in Microfinance Institutions}

Informal savings and credit systems such as 'Tontines' (or Rotating Saving and Credit Association, ROSCA) in West Africa and Latin America, are inadequate to satisfy a multitude of small borrowers with high expenditure and low income. According to Armendáriz and Morduch (2007), the desire of micro savings instigated the first microfinance movements focusing exclusively on microcredit. Afterwards, it has led to a diversification in the activities of microfinance institutions with increasing importance on the collection of savings. However, some MFIs combine both credit and deposit accepting activities. And, by so doing constraint their customers to save before credit might be granted to them. Historically, the granting of microcredit (small amount of loans) marked the beginning of the activities of MFIs. Indeed, an increase of the lending amount depends on the loan repayment potential of the borrowers. Initially, members are to behave well, if they want to benefit from successive microcredit. Such an initiative, according to Morduch (1999) and Simtowe et al (2006), is likely to motivate individuals to meticulously choose their members when forming groups, to be implicated in monitoring, and also to use social pressure on defaulting members. The repetitive characteristics of revolving lending and borrowing programmes (and the threat to reject defaulting customers) might be exploited to improve the stringency of contracts. Meanwhile, the remarkable pressure on individuals with low and irregular incomes is to settle their debts in a single payment (Yunus, 2003). Accordingly, Grameen Bank has opted for the repayment of microcredit in instalments. According to Morduch (1999), this strategy has numerous benefits. For instance, it is a means banks employ to monitor; that is, to assess the behaviour of their customers. Thus, only best customers will be selected in the next phase of the credit schemes. It is also a way to avoid the diversion of cash for other purposes by borrowers.

\subsubsection{Distribution of Clients and Microfinance Institutions in the Global Sphere}

According to the report of the World Microcredit Summit in 2006 and the micro banking Bulletin 2006, it is observed that by the end of 2005, microfinance institutions occupied at least $114,669,100$ borrowers, holding a loan with at least 3,289 institutions across the world. Notwithstanding, the interest rates charged by MFIs are between the base rate and the usury rate varying from one country to another country. In 2003, for example, in India, MFIs practice $17 \%$ annual rate, while banks charged their loans at $13 \%$ and some usurers $360 \%$ annually (with an inflation rate of 5\% in 2003). In Morocco, MFIs operated at a rate of 2 to $3 \%$ per month (36\% annually) while usurers applied 10 to $20 \%$ monthly and commercial banks charged $12 \%$ annual (inflation rate of $1.6 \%$ ). In 
West Africa, it can be seen that MFIs had an interest rate of around $27 \%$ to $30 \%$ per annum, the bank rate being 17 to $25 \%$, meanwhile, lending sharks practiced a rate of around 20\% per month (Planet Finance, 2013).

Over the past decade, new programs have been launched in Africa, Asia, Latin America, Canada, Europe, the United States and Eastern Europe. It is currently estimated that there are about 8 to 10 million households that benefit from microfinance programs. Microfinance practitioners intended to reach 1,000 million households in 2009. According to James Wolfensohn (Note 13), by helping 1,000 million households, implies that 500 to 600 million people would be affected by microfinance programs. According to a recent study (quoted by Morduch, 1999), most programs only cover $70 \%$ of their costs. As a result, the weak performance of microfinance institutions is likely to continue, even for institutions strongly committed to the fight against poverty such as the Grameen Bank.

\section{Research Hypothesis}

Based on the critical review of literature, we formulate the hypothesis of this study as follows:

$\mathbf{H}_{1}-$ The socioeconomic characteristics of borrowers influence microcredit repayment behaviour.

\section{Methodology}

We exploited secondary data sourced from the data base of CCA (Note 14). The data base consists of 1805 individual loan contracts, credit records and follow-up files from the period 2007-2014. As said before, the ultimate choice on CCA is justifiable from the figures published by the report of COBAC (2014), which categorised CCA as the best category II MFIs in terms of lending and microcredit recovery rate during this period. However, concerning the empirical analysis of borrowers' behaviour, we had two possibilities. The types of borrowers' behaviour were captured based on their loan repayment potential during this period. Indeed, the information sourced from individual credit records of clients enabled to capture the behaviour of the borrowers towards the repayment of microcredit.

\section{Statistical Analysis and Probit Regression Results}

Probit regression statistical model was convoked to analyse our data. As a result, we developed the following empirical model:

$\operatorname{Pr}(\mathrm{Y}=1)=\varnothing(\beta 0+\beta 1$ sex $+\beta 2$ age $+\beta 3$ busi_dur $+\beta 4$ educ_lev $+\beta 5$ sect_act $+\beta 6$ income $+\beta 7$ wealth $+\beta 8$ collat $+\beta 9$ marital-stat $+\beta 10$ local $+\varepsilon$.

A Probit model which is similar to what Varadharajan (2004) used in his analysis of ROSCA (Note 15). The dependent variable took the value of one (1) if respondents did not default on payment and zero (0) otherwise. It is dichotomy (dummy) variable representing the repayment behaviours of borrowers. $\boldsymbol{\varepsilon}$ represents the error term, and $\beta_{0}$ is the constant term.

5.1 Presentation and Interpretation of Results

Table 1.1 Probit Regression Results

\begin{tabular}{|c|c|c|c|c|c|}
\hline \multicolumn{2}{|l|}{ Probit regression } & $\begin{array}{c}\text { Number of obs } \\
\text { Wald chi2 (9) } \\
\text { Prob }>\text { chi2 } \\
\text { Pseudo } \text { R }^{2}\end{array}$ & $\begin{array}{l}= \\
= \\
= \\
=\end{array}$ & $\begin{array}{l}1805 \\
492.71 \\
0.0000 \\
0.8093\end{array}$ & \\
\hline \multirow{12}{*}{ Log pseudolikelihood $=$} & not default & coef & & Std. Err & $\mathrm{p}>\mathrm{z}$ \\
\hline & sex & 0.1242938 & & 0.0380268 & 0.725 \\
\hline & age & -0.454005 & & 0.6275542 & 0.965 \\
\hline & busi-dur & 3.528124 & & 0.7550768 & 0.002 \\
\hline & educ-lev & 5.123173 & & 1.246275 & 0.000 \\
\hline & sect-act & 5.123173 & & 0.8109385 & 0.000 \\
\hline & income & -0.002145 & & 0.0006727 & 0.003 \\
\hline & wealth & 0.020337 & & 0.0025375 & 0.000 \\
\hline & collat & 0.374924 & & 0.7456323 & 0.647 \\
\hline & marital-stat & -0.529420 & & 0.5786569 & 0.475 \\
\hline & local & 0.642783 & & 0.5270193 & 0.321 \\
\hline & const & -12.5605 & & 2.787453 & 0.000 \\
\hline
\end{tabular}

Source: Field survey 
Table 1.2 Marginal Effect from the Probit Estimates

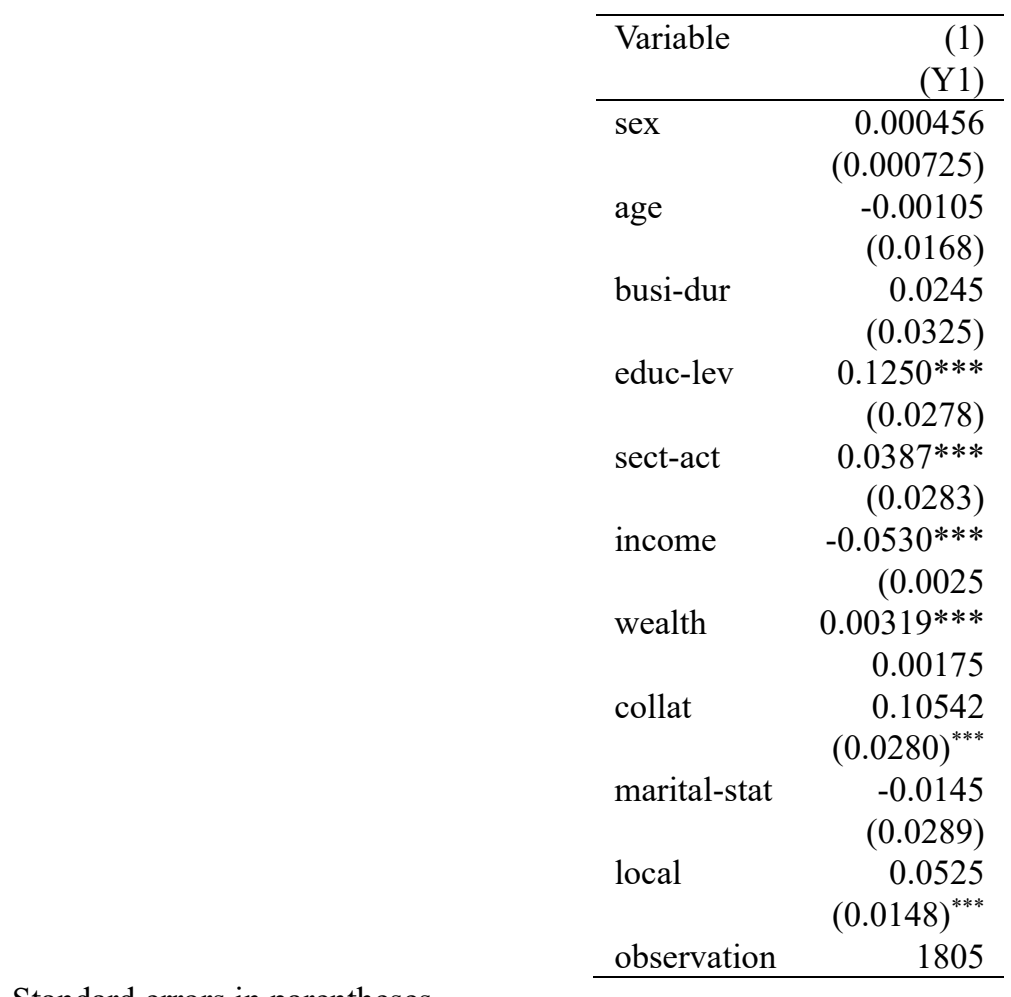

Standard errors in parentheses

$* * * \mathrm{p}<0.01, * * \mathrm{p}<0.05, * \mathrm{p}<0.1$

From the regression analysis, the Pseudo $R 2$ of 0.8093 implies that about $80.93 \%$ of the variation in the loan repayment behaviour of borrowers is explained by the model. On the other hand, the test of Chi-square predicts the pertinence of the null hypothesis attests the robustness of the model. The value of chi-square (i.e., 492.71) for 9 degrees of freedom is significant at the $1 \%$ level. This value confirms the significance of our empirical model of analysis.

Table 1.1 above shows the results of Probit regression. The Probit model was used to analyse loan repayment behaviour of borrowers. The dependent variable took the value of one if borrowers did not default on microcredit payment and 0 other wise. With educational level, the highest level education of each borrower captured our interest. Those with secondary/vocational, HND (Note 16)/diploma, university, and professional qualification were classified as highly educated borrowers and those with no education and primary/JHS/middle were regarded as borrowers with no or low level of education.

The result of the study show that age, sex, and applying for loan to either start a new business or provide financing to an existing one, and marital status of borrowers are not statistically significant. However, educational level, sector of activities, income stability of borrowers, awareness about the location of business and/or location by lenders, availability of collateral and wealth of borrowers were found to be statistically significant. However, from the results above, educational level, sector of activities, collateral, location and wealth have a positive influence on the probability of predicting the likelihood of borrowers not to default on credit. Meanwhile, income has a negative influence in predicting default on microcredit. Educational level is significant at $1 \%$ and it indicates that, borrowers who have no or low level of education are more likely not to default on payment. The marginal effect of educational level on the other hand indicates that $1 \%$ increase of educational level will increase the probability not to default on microcredit by $12.5 \%$. Both sector of activities and wealth of borrowers are all significant at $1 \%$. The marginal effect of sector of activities indicates that the sector of activities in which a borrower operates increases by $1 \%$ the probability he/she does not default by $3.87 \%$. On the other hand, from the marginal effect of wealth, the probability that a borrower possessing wealth does not default on loan is $3.19 \%$. In addition, income significantly influences the loan repayment decisions of borrowers. Although, income is found to be significant at $1 \%$, it has a negative influence on predicting the microcredit repayment attitudes of borrowers. The marginal effect of income indicates that a unit increase in borrower's income will decrease the probability of 
not defaulting by $5.37 \%$. Moreover, collateral has a positive influence on the probability of borrowers not to default on credit payment, and is statistically significant at $1 \%$. Indeed, the marginal effect of collateral shows that an increase in real assets of borrowers' by $1 \%$ will increase the probability not to default on loans by $10.542 \%$. Furthermore, business and/or residence localisation of borrower is sought to be $1 \%$ significant. The marginal effect of awareness about business and/or residence location by lenders reveals that an increase in awareness about business location by $1 \%$ increases the likelihood not to default on payment of microcredit by $5.25 \%$.

Conclusively, sex, age, marital status, and business duration are not statistically significant. Thus, whether the individual participant is a child, youth or aged doesn't predict his/her loan repayment behaviour. Again, whether the individual is a male or female doesn't predict his/her behaviour to either default or not on loan repayment. Moreover, whether a borrower is married or not does not predict his/her loan repayment behaviour. Furthermore, whether an individual apply for loan to either create a business or seek financing for an established business does not predict his/her loan repayment behaviour.

\section{Conclusion}

The findings of this study indicate that socioeconomic characteristics influence microcredit repayment behaviour of borrowers. Therefore, the aforementioned hypothesis is accepted. For example, the results of the regression analysis show that gender, age, business duration, and marital status are not significant. Meanwhile, educational level, wealth, income, sector of activities, awareness about location of business and/or residence by lenders and collateral are sought to be statistically significant. For instance, the fact that the borrower's residence and/or business premises are/is known by the lender impose(s) on borrowers not to default on their financial obligations towards microfinance. This can be explained by a frequent monitoring by the lender and the necessity to obtain a good reputation on the side of the borrower. Also, the availability of real assets and the existence of wealth increase the probability of borrowers not to default on loans. This can be explained by the fear to loss the assets prior to a defaulting situation, and the capacity to pay back microcredit with personal property (wealth) at maturity. Our finding highlights the importance of securing loans by MFIs. The sector of activities is sought to influence the loan repayment behaviour of borrowers. Obviously, borrowers in sectors where the activities are booming may definitely not default on their financial obligations towards microfinance institutions. Educational level is sought to influence mostly the likelihood of borrowers not to default on microcredit repayment. In fact, an increase in the level of education is symbol of an effective business management skill. For instance, borrowers with high level of education might know when to apply for a loan to finance their activities. In addition, they might be aware of the value added of the business derived from the borrowed funds. It implies that they have the capacity to assess the leverage effect of the debt to the business. Also, the level of education and the type of vocational training bestow knowledge of business management susceptible to generate high profit necessary to pay back loans. On the other hand, income stability (permanent) influences the loan repayment behaviour of borrowers. Borrowers with stable income (or stable employment) may likely not default on loan, because incomes might be used to reimburse microcredit; supposedly, the business does not generate enough cash-flows. Therefore, income constitutes an assurance to both the borrowers and lenders.

However, despite the paramount theoretical and empirical potential of this study, the results of our finding are obtain from a single data base of a category II microfinance institutions (CCA). Explicitly, we have exploited a data base of customers (borrowers) from a single microfinance institution. Therefore, the absolute reliance on a single microfinance institution may partially explain the link between microcredit reimbursement behaviour and socioeconomic characteristics of borrowers. As a result, it is important for further studies to utilise a broad data base of customers of a variety of microfinance institutions in order to amplify the empirical and theoretical rigour of this study. Additionally, further studies may conduct a cross-sectional study to compare the relationship between microcredit repayment behaviour and socioeconomic characteristics of borrowers across various categories of microfinance institutions. Naturally, a transversal study across various categories of MFIs will enrich the results of this study. Moreover, our study emphasised primarily on socioeconomic characteristics of the borrowers. Sincerely, other issues not related to the socioeconomic characteristics of borrowers might affect their loan repayment behaviours. Therefore, it is important for further studies to highlight the influence of other factors (such as the characteristics of the loan) on the loan repayment behaviour of borrowers towards microfinance institutions.

\section{References}

Altman, E. I. (1968). Financial ratios, discriminant analysis and the prediction of corporate bankruptcy. The Journal of Finance.

Armendariz, B., \& Morduch J. (2005). The Economics of Microfinance. MIT Press.

Arnaud, de S., \& Ivan, Z. (1999). Economie Financière. Manuel, Dunod. 
Atiya, A. F. (2001). Bankruptcy Prediction for Credit Risk Using Neural Networks: A Survey and New Results. IEEE Transactions on Neural Networks, 12(4), 929-935. https://doi.org/10.1109/72.935101

Banerjee, A. V., \& Duflo, E. (2007).Repenser la pauvreté. World Development Indicators.

Bardos, M. (1989).Trois méthodes d'analyse discriminante. Cahiers économiques et monétaires, 33, Banque de France, 151-189.

Besley T., \& Coate, S. (1995). Group lending, repayment incentives and social collateral. Journal of Development Economics, 46, 1-18. https://doi.org/10.1016/0304-3878(94)00045-E

Bester H. (1985). Screening vs. Rationing in Credit Markets with Imperfect Information. American Economic Review, 75, 850-855.

Black, F., \& Scholes, M.(1993). The Pricing of Options and Corporate Liabilities. Journal of Political Economy, May- June, 637-659.

Blazy, R., Charlety, P., \& Combier J. (1993). Les défaillances d'entreprises: des difficultés visibles plusieurs années à l'avance. Economie et Statistique, 101-111. https://doi.org/10.3406/estat.1993.5813

Boye, S., Hajdenberg, J., \& Poursat, C. (2006). Le Guide de la microfinance", microcrédit et épargne pour le développement, Organisations, 303p.

Carmichael, J., \& Pomerleano, M. (2002). The Development and Regulation of Non- Bank Financial Institutions. The World Bank. https://doi.org/10.1596/0-8213-4839-6

CGAP. (2017). Effective governance for Micro-finance Institutions. FOCUS, 7, mars.

Chevallier- Farrat. (1992). Pourquoi des banques? Revue d'Economie.

Ding, Y., Song, X., \& Zen, Y. (2008). Forecasting financial condition of Chinese listed companies based on support vector machine. Expert Systems with Applications. https://doi.org/10.1016/j.eswa.2007.06.037

Fama, E. (1985). What's different about banks? Journal of Monetary Economics, 15. https://doi.org/10.1016/03043932(85)90051-0

Fama, E., \& Jensen, M. C. (1983b). Separation of Ownership and Control. Journal of Law and Economics, 26(June), 301-326. https://doi.org/10.1086/467037

Godlewski, C. J. (2003). Excès de risque et défaillance bancaire: Une application des modèles de prévision de défaut aux banques des pays émergents.Working paper, Laboratoire de Recherche en Gestion et Economie.

Godquin, M. (2004). Microfinance Repayment Performance in Bangladesh: How to Improve the group lending”, Economic of Transition, 8(2), 401-420.

Guerin, I., \& Roesch, M. (2005). Microcredit, Outil fragile. Le monde, 30 novembre.

Guerrien, B. (2002). Dictionnaire d'analyse économique': microéconomie, macroéconomie, théorie des jeux, etc, 3ème édition. Repères, La découverte, Paris.

Hol, S., Westgaard, S., \& Wijst, V. N. (2002). Capital structure and the prediction of bankruptcy. EWGFM Conference, Capital Markets Research (Bankruptcy Prediction).

Honohan (1997). Banking Systems faillures in develoing and transition countries: Diagnosis and predictions. WP, Bank of International Settlements. https://doi.org/10.2139/ssrn.860624

Hugon, P. (1996a). Incertitude, précarité et financement local: Le cas des économies africaines. Revue Tiers Monde, 37(145), 13-40. https://doi.org/10.3406/tiers.1996.5026

Huppi, M., \& Feder, G. (1990). The Role of Groups and Credit Cooperatives in Rural Lending. The World Bank Research Observer, 5(2). https://doi.org/10.1093/wbro/5.2.187

Labie, M. (2004). Microfinance: un état des lieux. Monde en Développement. https://doi.org/10.3917/med.126.0009

Lanha, M. (2004). Efficacité relative du prêt de groupe avec caution solidaire.Séminaire de Recherche, Laboratoire d'Economie d'Orléans, Février 2004.

Ledgewood, J. (1998). Manuel de Microfinance: Une Perspective Institutionnelle et Financière. Banque Mondiale, Washington, D.C.

Lelart, M. (2005). De la Finance Informelle à la Microfinance. Savoirs Francophones.

Lewis, M. (1992). Modern Banking in Theory and Practice.Revue Économique. https://doi.org/10.2307/3501990 
Li, H., \& Sun, J. (2009). Gaussian case based reasoning for business-failure prediction with empirical data in China. Information Sciences, 179(1-2), 89-108. https://doi.org/10.1016/j.ins.2008.09.003

Liang, L., \& Wu, D. (2003). An application of pattern recognition on scoring Chinese corporations financial conditions based on back propagation neural network. Computers and Operations Research, 32, 1115-112. https://doi.org/10.1016/j.cor.2003.09.015

Lobez, F. (1997). Banques et marchés du crédit. Presses Universitaires de France.

Lobez, F., \& Vilanova, L. (2006). Microéconomie bancaire.Collection Finance, PUF. https://doi.org/10.3917/puf.lobe.2006.01

M.I.X. (2009). Microfinance Information Exchange.

Markowitz, H. (1952). Portfolio Selection. Journal of Finance, March 1952, 77-91. https://doi.org/10.2307/2975974

Mayers, D., \& Smith, C. W. (1981). Contractual provisions, Organisation structure and conflict control in insurance markets. Journal of Business. https://doi.org/10.1086/296138

Mayoukou, C. (2000). La microfinance en Afrique Centrale: état des lieux et perspectives de développement. Techniques financières et développement, 59-60.

Montalieu, T. (2002). Les institutions de micro-credit: Entre promesses et doutes. Quelles pratiques bancaires pour quels effets? Mondes en Développement, 119. https://doi.org/10.3917/med.119.0021

Morduch, J. (1998). Does microfinance really help the poor? New evidence from flagship programme in Bangladesh. Department of Economics, Harvard University.

Muhamad, Y. (1997). Vers un monde sans pauvreté. LATTES, Paris.

Ntieche, A. (2018). Contrats de dette et comportements des emprunteurs dans le secteur de la microfinance, thèse de Doctorat (PhD), Université de Douala.

O.C.C. (1988). Bank failure: An evaluation of the factors contributing to the failure of national banks.

Pankaj, J., \& Moore, M. (2003). What Makes Micro-credit Programmes Effective? Fashionable Fallacies and Workable Realities. Institute of Development Studies.

Pindado, J., \& Rodrigues, L. F. (2001). Parsimonious models of financial insolvency in small companies. Working Paper, SSRN Working Paper Series. https://doi.org/10.2139/ssrn.283782

Tamari, D. (1964). Sur quelques problèmes d'associativité. Annales scientifiques de l'Université de ClermontFerrand 2, tome 24, série Mathématiques, 3, 91-107.

Varadharajan, S. (2004). Explaining participation in rotating savings and credit associations (roscas): Evidence from indonesia. Department of Economics, Cornell University.

\section{Notes}

Note 1. FCFA - Francs of Africa Financial Community.

Note 2. COBAC - Banking Commission of Central Africa.

Note 3. DGTCFM - Direction of Treasury and Monetary and Financial Committee.

Note 4. MFIs - Micro finance Institutions.

Note 5. EMFs- Establishments of Micro finance.

Note 6. CAMCCUL - Cameroon Cooperatives Credit Union League.

Note 7. CVECA - Rural savings and self-managed credits.

Note 8. CMEC-Economic and monetary community of West African States.

Note 9. ATMs - Automatic Teller Machines.

Note 10. COFINEST - Estuary Financial Cooperative.

Note 11. SMEs - Small and Medium-size Enterprises.

Note 12. SMIs- Small and Medium-size Industries.

Note 13. James Wolfensohn - President of the World Bank. 
Note 14. CCA - Credit Community of Africa.

Note 15. ROSCA - Rotating Savings and Credit Association.

Note 16. HND - Higher National Diploma.

\section{Copyrights}

Copyright for this article is retained by the author(s), with first publication rights granted to the journal.

This is an open-access article distributed under the terms and conditions of the Creative Commons Attribution license (http://creativecommons.org/licenses/by/4.0/). 